\title{
Crowd Sourced Governance in a Post-Disaster Context
}

HKU Working Paper Series, 2013

\author{
Shahla F. Ali ${ }^{1}$
}

\section{Abstract:}

In the wake of recent catastrophic natural disasters, the United Nations ("UN") has developed an increasingly sophisticated network of collaborative partnerships to assist with humanitarian relief operations. The growing use of open source technology such as crowd mapping and resource tracking being universally accessible, collaboratively designed, subject to ongoing improvement, and responsive to on-the ground needs, reflects in many respects the emerging UN governance mechanisms developed to support the creation of such technology. The 2008 meeting of the World Economic Forum called for increased documentation and "dissemination of the work of humanitarian relief to both the humanitarian sector and private sector firms, mapping of assets, non-food items" and resources to prevent duplication. ${ }^{2}$ However, as yet, little attention has been given to the role of open source governance mechanisms in the context of disaster response. This paper aims to fill this gap by examining the emerging mechanisms by which private sector collaboration is coordinated by international institutions such as the UN. It finds that the emergence of post-disaster open source humanitarian relief reflects the observations of new governance legal scholars that coordination is increasingly the result of expanded participation and partnership on the part of governments and non-state actors, a learning-focused orientation, with the state increasingly acting as a convener, catalyst and coordinator.

\footnotetext{
${ }^{1}$ Assistant Professor and Deputy Director, Program in Arbitration and Dispute Resolution, Faculty of Law, University of Hong Kong. BA, Stanford University; JD, Boalt Hall School of Law, University of California at Berkeley; PhD, Jurisprudence and Social Policy Program, University of California at Berkeley. The author thanks the Government of Hong Kong's University Grants Committee for its kind support through its ECS Grant (HKU 757412H).

${ }^{2}$ World Economic Forum (2008). P2
} 


\section{Introduction}

Due to the multi-factorial nature of humanitarian relief, at present practical, legal, political and financial considerations have lead to diverging approaches to the development of humanitarian relief policy. Concerted efforts by the United Nations ("UN") and its subsidiary bodies have, to a large extent, coordinated many areas of relief. At the same time, a growing number of public-private partnerships are emerging, among them are those involved in the development of open source technology for humanitarian relief efforts. Many of the technological developments for humanitarian relief are spontaneous and postdisaster, such as in response to Hurricane Katrina, the Haiti earthquake and Japan Tsunami.

Since the adoption of General Assembly resolution 46/182 in 1991which provides the basic framework for humanitarian assistance, the UN has passed multiple resolutions almost annually to expand its intergovernmental humanitarian framework. ${ }^{3}$ These resolutions address various issues such as humanitarian access; internally displaced persons; safety and security of humanitarian personnel; prevention preparedness and capacity building; transition; emergency relief, financing and coordination; and other mechanisms and information management crucial to the efficacy of humanitarian relief. ${ }^{4}$

The UN has also recognized the importance of global partnerships. Especially in light of the UN Millennium Development Goals ("MDGs"), developed in 2000, Resolution $56 / 76$ was passed in 2001 encouraging the development of partnerships by providing greater opportunities for collaboration among the private sector, non-governmental organizations ("NGOs") and civil society so as to contribute toward the realization global development objectives. ${ }^{5}$ In particular, especially in the technology sector, the UN has recognized the ability of the private sector to contribute not only financial and human resources but also access to technology, management expertise and support. ${ }^{6}$

This paper, following a discussion of (1) the major strategies employed by the UN in humanitarian relief operations, provides (2) a context for analyzing the emerging development of open-source solutions by examining the work of legal scholars writing in the emerging field of new governance. It (3) examines the implementation of global-local open source technology for humanitarian relief at the UN including an analysis of "disaster relief 2.0 " and finally offers a (4) set of policy recommendations on the role of partnerships to advance more efficient usage of open source technology for humanitarian relief efforts.

\section{Part I. Coordinating Technology Development for Humanitarian Relief at the UN}

The UN has adopted two main strategies to facilitate humanitarian relief efforts. First, through the direct use of some its key bodies (and through the coordination of the

\footnotetext{
${ }^{3}$ Office for the Coordination of Humanitarian Affairs ("OCHA"). Compilation of United Nations Resolutions on Humanitarian Assistance (2009), p1

${ }^{4}$ Ibid

${ }^{5}$ UN Resolution 2001, A/RES/56/76. Towards global partnerships. Available at

http://www.unglobalcompact.org/docs/issues_doc/un_business_partnerships/A_RES_56_76.pdf

${ }^{6}$ Ibid
} 
UN/UN-related organizations such as the UN Office for the Coordination of Humanitarian Affairs ("OCHA") and the Inter-Agency Standing Committee ("IASC") to provide humanitarian relief. Secondly, through the work of the UN Foundation, which promotes, and provides support through partnerships with the private sector.

There are a number of entities within the UN that oversee humanitarian aid. ${ }^{7}$ In addition to the UN Office for Coordination of Humanitarian Affairs ("OCHA") ${ }^{8}$ there are six key agencies of the UN system which have mandates pertaining to humanitarian assistance. They are the original members of the Inter-Agency Standing Committee ("IASC"), namely, the United Nations Development Programme ("UNDP"), the United Nations Children's Fund ("UNICEF"), the Office of the High Commissioner for Refugees ("UNHCR"), the World Food Programme ("WFP"), the Food and Agriculture Organization ("FAO") and the World Health Organization ("WHO"). These entities are also among the top recipients of the funds from UN Central Emergency Response Fund ("CERF"). ${ }^{9}$ The UNHCR is the only one of the six bodies that has an exclusive humanitarian mandate. ${ }^{10}$

Given the number of UN agencies and private partnerships working in the area of humanitarian technology development for post-disaster relief, the UN has developed mechanisms to coordinate their collective efforts. They include, the Emergency Relief Coordinator ("ERC"), the IASC, and the Humanitarian Field Coordination and Information Management mechanisms. ${ }^{11}$.

\section{UN Office for Coordination of Humanitarian Assistance}

The OCHA is arguably the most important mechanism for the coordination of international relief efforts. It is the part of the UN Secretariat responsible for bringing together humanitarian actors to ensure that there is a coherent "framework within which each actor can contribute to the overall response effort". 12

When an emergency occurs, the OCHA starts working with key partners to produce information to support coordination of all humanitarian organizations and a response operation. These include the "Who What Where $(3 \mathrm{~W})$ database, contact lists and meeting schedules. Tools such as the information needs assessment and maps are made available to support relief planning and action". ${ }^{13}$

\section{Inter-Agency Standing Committee}

The IASC is a unique inter-agency forum "for coordination, policy development and decision-making involving the key UN and non-UN humanitarian partners"14 at the global,

\footnotetext{
${ }^{7}$ OCHA. Independent Analysis: Normative decisions of key governing bodies of funds, programmes and specialized agencies of the United Nations System in humanitarian assistance (2008). Available at http://ochanet.unocha.org/p/Documents/Reference\%20Guide\%20-\%20Phase\%20II\%20-\%20Independent\%20Analysis.pdf ${ }^{8}$ OCHA. Reference Guide: Phase II. (2009) Available at http://ochanet.unocha.org/p/Documents/Reference\%20Guide\%20-\%20Phase\%20II\%20-\%20Final.pdf 
regional and country levels. It "plays a key role in preventing gaps and duplications in humanitarian response with real-time evaluations and feedback mechanisms to improve the quality of assistance". ${ }^{15}$

Relevant to the issue of utilizing technology in humanitarian aid, the IASC has developed a set of guidelines to help national authorities and humanitarian organizations exchange data, thereby improving the effectiveness of humanitarian response. These guidelines "outline the common datasets needed for response in humanitarian emergencies, as well as the governance model for the management of the data (i.e. accountability and responsibility). ${ }^{16}$ These guidelines also recognize the primary role of the State affected by the disaster to organize, coordinate and implement humanitarian assistance within its territory. ${ }^{17}$ To this effect, these guidelines aim to ensure that the Common Operational Datasets ("CODs") support national information systems and standards, build local capacities and maintain appropriate links with relevant government, state and local authorities." 18

\section{UN Foundation and Partners}

Apart from sole and direct action by UN bodies, the United Nations Office for Partnerships ("UNOP”) serves as a gateway for partnership opportunities with the UN organization. The UNOP provides Partnership Advisory Services and Outreach to a variety of entities, as well as manages the United Nations Fund for International Partnerships ("UNFIP"). ${ }^{19}$ In establishing public-private collaboration for humanitarian action, the UN works according to the guiding principles of: ${ }^{20}$ promoting cooperative relationships with government; building local capacity; focusing on existing needs, and systematic reporting, monitoring and evaluation.

The bulk of UNOP's work is funded and mandated by the UNFIP, which focuses on Technology partnerships among other areas of concern. The UNOP's focus on technology partnerships has direct implications for the support of open source governance development programs at the grass roots. For example, the UN Partnership Annual Report 2010 highlighted the UN Foundation's achievements in its technology partnerships with mobile phone operators such as Vodafone to strengthen humanitarian efforts of the UN through the use of wireless technology. The initiative focuses on mobile health initiatives for development and emergency response communications to support disaster relief and aims to "harness the ubiquity of mobile communications to address pressing challenges in the developing world". ${ }^{21}$

The UNFIP also funds the Mobile Health (mHealth) for Development programme to support health data collection in Africa using mobile devices. Funding also supports building an Information Communications Technology (ICT) Humanitarian Emergency

\footnotetext{
${ }^{15}$ OCHA. Inter-Agency Standing Committee. (2011), p2

${ }^{16}$ ISCA. Guidelines on Common Operational Datasets in Disaster Preparedness and Response. (2010), p1

${ }^{17}$ ISCA. Guidelines on Common Operational Datasets in Disaster Preparedness and Response. (2010), p1

${ }^{18}$ ISCA. Guidelines on Common Operational Datasets in Disaster Preparedness and Response. (2010), p1

${ }^{19}$ UNOP. Welcome to the United Nations Office for Partnerships. Available at http://www.un.org/partnerships/

${ }^{20}$ World Economic Forum and OCHR. Guiding Principles for Public-Private Collaboration for Humanitarian Action. (2007) Available at http://www.un.org/partnerships/Docs/Principles\%20for\%20PublicPrivate\%20Collaboration\%20for\%20Humanitarian\%20Action.pdf

${ }^{21}$ UN Foundation. UN Partnership annual report 2010, pp7-8. Available at http://www.un.org/partnerships/Docs/A_65_347.pdf
} 
Platform that will standardize ICT response capabilities through the humanitarian community. ${ }^{22}$

\section{Part II. New Governance Scholarship in the Post Disaster Context}

The development of global technology partnerships between the UN and the private sector in the post-disaster aid context can be situated in the insights arising from new governance scholarship. Beginning in the late 1990's legal and social science scholars began to explore the unique insights of new governance mechanisms within a range of public and private sector arenas. This has included thoughtful analysis of the contribution of new governance to expanded participation and partnership on the part of governments and non-state actors in solving public problems ${ }^{23}$; the questioning of doctrinal divides between legal fields ${ }^{24}$; a learning-focused orientation ${ }^{25}$; the use of public private partnership in regulatory reform ${ }^{26}$; the role of the state as a convener, catalyst and coordinator ${ }^{27}$; and the relationship between new governance and development of problem-solving capabilities ${ }^{28}$. In addition, recent scholarship has examined the challenges facing new governance; including ensuring participants have the necessary skills for participation ${ }^{29}$, the development of managerial and procedural safeguards ${ }^{30}$, the difficulties of achieving stakeholder participation under conditions of social conflict ${ }^{31}$ and distributional inequalities ${ }^{32}$.

Yet, while both the opportunities and challenges of new governance mechanisms have been examined, as yet, little attention has been given to the role of new governance mechanisms in developing open source technologies to address humanitarian disaster response. Recent work has begun to call for specific examination of the applications of new governance approaches in the context of humanitarian aid. Specifically, research into new modes of governance must take into account dynamic social and migrant networks that enhance resilience in flexible rather than control-based ways. ${ }^{33}$ This paper aims to fill this gap by examining the emerging mechanisms of public-private crowd sourced collaboration in the post-disaster context.

\footnotetext{
${ }^{22}$ Ibid

${ }^{23}$ Lobel (a); Solomon, Jason M., 'Law and Governance in the 21st Century Regulatory State', Texas Law Review, 86 (2008), p. 819-856

${ }^{24}$ Lobel, Orly, 'The Renew Deal: The Fall of Regulation and the Rise of Governance', Minn. L. Rev., 89 (2004(b)), p. 342

${ }^{25}$ Solomon, loc. cit.; Cohen, Amy J., 'Negotiation, Meet New Governance: Interests, Skills, and Selves.' 33 Law \& Soc. Inquiry, 33(2008), p. 503.

${ }^{26}$ Alexander, Lisa T., 'Stakeholder Participation In New Governance: Lessons From Chicago's Public Housing Reform Experiment.', Geo. J. Poverty Law \& Pol'y, 16 (2009), p. 117

${ }^{27}$ Dorf, Michael C. \& Sabel, Charles E.. 'A Constitution of Democratic Experimentalism.' Colum. L. Rev., 98 (1998), p. 267; Solomon, loc. cit.; Cohen, loc. cit.

${ }^{28}$ Cohen, loc. cit.

${ }^{29}$ Ibid.

${ }^{30}$ Salamon, Lester M., 'The New Governance and the Tools of Public Action: An Introduction.' Fordham Urb. L.J., 28 (2001), p. 1611

${ }^{31}$ Alexander, loc. cit.

32 Ibid.

${ }^{33}$ Assessing Institutional and Governance Needs Related to Environmental Change and Human Migration by Koko Warner (Funded by the German Marshall Fund, the US). Available at: http://www.ehs.unu.edu/file/get/5301
} 
In beginning to examine insights from new governance scholarship, it is important to first understand its relationship to "old forms of governance." New governance has typically been understood as involving multi-stakeholder decision making and rule-making. However, such decision-making approaches have tended face limits when applied in the context of wide-scale humanitarian suffering. One example of this interplay between new and old governance forms has been examined in the context of setting appropriate humanitarian standards in global supply chains ${ }^{34}$ through which a mix of legislation ('old governance') and multi-stakeholder involvement ('new governance') have been considered preferable to sole reliance on new governance approaches alone.

In particular, new governance approaches have been found to be relevant when the insights and shared learnings of a broad range of stakeholders are required to address a complex or newly identified social problem because new governance tends to foster dialogue ${ }^{35}$. The 1990s saw the proliferation of new-governance approaches to decisionmaking. ${ }^{36}$ This has been particularly true when rules are needed to address a novel or rapidly evolving situation that demands an ability to alter the rules if necessary ${ }^{37}$. In such circumstances, the command-and-control mechanisms in old governance is arguably limited because regulators may not have the expertise to devise appropriate rules, nor the resources needed to enforce them in multiple jurisdictions ${ }^{38}$.

\section{Principles of New Governance}

In relation to new governance generally, scholarship places primacy on (1) collaborative process, (2) stakeholder participation, (3) local experimentation, (4) public/private partnership, and (5) flexible policy formation, implementation, and monitoring 39 .

New governance places stakeholder participation as central to decision making processes ${ }^{40}$. Participatory process recognizes diverse stakeholders in public problems and attempts to give those stakeholders a voice in policy formation ${ }^{41}$. In participatory governance, stakeholders, including organizations (institutions, public agencies, private firms and NGOs), interact, share responsibility, and together generate policy ${ }^{42}$. States and localities are expected to be better situated to facilitate participatory processes, and once solutions are found, they are best suited to monitor implementation ${ }^{43}$.

New governance stresses public/private partnerships. Public problems are not

\footnotetext{
${ }^{34}$ Lehr, Amy. "Old and New Governance Approaches to Conflict Minerals: All are Better than One". 58 Harvard Int'l Law Journal 148, 151 (2010)

35 Ibid, 153, and Jason M. Solomon, New Governance, Preemptive Self- Regulation, and the Blurring of Boundaries in Regulatory Theory and Practice, 2010 WIS. L. REV. 591, 598 (2010).

36 Ibid, 152

37 Ibid, 152-153

38 Ibid, 153

39 Ibid, 332

40 Ibid, 333

${ }^{41}$ Ibid

42 Ibid

43 Lobel, Orly. "The Renew Deal: The Fall of Regulation and the Rise of Governance in Contemporary Legal Thought" 89 Minn. L. Rev. 342 (2004), at 381-382
} 
entrusted merely to public agencies, but instead private interests affected by public action involve themselves in policy formation. In this sense, new governance places the focus on 'the relationships among private and public actors rather than on the substantive prescription of state legislation, rules, and judicial decisions' ${ }^{44}$. This public-private rethinking attempts to harness the late-twentieth century turn toward private firms and markets to provide what had otherwise been public services ${ }^{45}$. The increased interdependence between public and private actors blurs previously stable boundaries between them ${ }^{46}$.

In terms of domains, new governance principles are wide reaching. Rooted in administrative and regulatory projects, scholars have applied them in an array of substantive domains - including employment, occupational safety, environmental regulation, community policing, corporate governance, community lawyering, anti-discrimination, constitutionalism, education, and healthcare ${ }^{47}$.

While the applications of new governance theory are wide ranging, scholars have argued $^{48}$ that much more analysis on an 'on the ground' basis must be conducted - and this necessarily includes both examples of success and failure ${ }^{49}$. This would include the need for greater on the ground collaboration of open source solutions to address post-disaster challenges.

\section{Applications of New Governance Approaches in the Humanitarian Context}

Looking specifically at the applications of new governance approaches to humanitarian aid, scholars have begun to examine the 'Cluster Approach', which is the UN's latest effort to impose order on the increasingly unwieldy environment of large-scale humanitarian catastrophes, especially since the 2005 Indian Ocean Tsunami and crisis in Darfur ${ }^{50}$. The key innovation of the Cluster Approach was the assignment of a 'lead agency' which 'is responsible for mapping needs, planning, monitoring, coordination and reporting in a given sector of humanitarian action. It acts as the first port of call and provider of last resort' 51 . The Cluster Approach works at two levels: global and countrylevels ${ }^{52}$. Global level clusters are standing bodies, where lead agencies coordinate standard setting, dissemination of best practices, and capacity building among responders ${ }^{53}$. Country-level clusters are assembled as needed when disaster strikes, and lead agencies are tasked with ensuring 'adequate coordination mechanisms... adequate preparedness, as well as adequate strategic planning ${ }^{\prime} 54$. Country clusters are often subdivided by geographic

\footnotetext{
${ }^{44}$ Lobel, Orly. "Setting the Agenda for New Governance Research", 89 Minn. L. Rev. 498, 505 (2004)

45 See Lobel, Orly (2004) supra note 46, at 373-374

${ }^{46}$ See $I d$, at 374

${ }^{47}$ See Nejaime, Douglas (2009) supra note 40, 338-341

${ }^{48}$ Susan Sturm, "Gender Equity Regimes and the Architecture of Learning", Law and New Governance in the $E U$ and the US 323 (Grainne de Burca \& Joanne Scott eds., 2006)

${ }^{49}$ See Nejaime, Douglas (2009) supra note 40, 346-347

50 Egeland, Jan. "Towards a Stronger Humanitarian Response System", 24 Force Migration Fev. IDP Supp.

$4(2005)$

${ }^{51} \mathrm{Ibid}, 4$

52 Inter-Agency Standing Committee [IASC], Guidance Note on Using the Cluster Approach to Strengthen Humanitarian Response, 2 (Nov. 24, 2006), 2

53 Ibid, $2-4$

${ }^{54} \mathrm{Ibid}, 10$
} 
scale, establishing national-level clusters in the capital and sub-national clusters at the provincial or local level ${ }^{55}$.

\section{The UN as a Humanitarian Coordinator}

The 'lead agency' of a local cluster is determined by the UN official overseeing operations (the 'Humanitarian Coordinator'), and it is not necessarily, though preferably, the same as lead agencies at the global level ${ }^{56}$. Clusters are activated in all 'major emergencies' and should be chosen on the basis of 'existing operations and capacities' within 48 hours ${ }^{57}$. Clusters are responsibile for coordinating with key partners and ensure that 'cross-cutting issues', such as gender, are properly taken into account ${ }^{58}$.

\section{Standardizing vs. Diversification}

Some scholars have suggested that the delegation of power by the UN to certain cluster leaders gives rise to two potential problems. ${ }^{59}$ First, given the significant influence of cluster leaders over decisions regarding policy and funding, there is a greater tendency for policy to move toward uniformity rather than allowing for experimentation and competition $^{60}$. This standardization in the cluster system, some have suggested, gives too much power to certain groups that are backed by powerful donors, thereby possibly channeling resources and funds to further the political goals of such donors, thus potentially risking the neutrality of humanitarian actors and frustrating access ${ }^{61}$.

Similarly, by selecting a 'lead agency' to manage the response in each sector, the Cluster Approach exercises a form of institutional choice that magnifies the power of a particular agency and brings its unique practices and principles to bear on an affected population $^{62}$. The lead agency has considerable power in choosing which actors will be involved in humanitarian efforts (and hence how funds should be distributed and which affected groups to attend to $)^{63}$.

\section{Accountability and Supervision in UN Humanitarian Assistance}

In response to questions regarding legitimacy and accountability, actors within the cluster system have begun to emphasize 'peer review' and 'horizontal accountability' as alternatives to a formal supervisory structure ${ }^{64}$. On paper, under the formal structure, the incountry Humanitarian Coordinator, a UN official, appoints and has the power to fire the

\footnotetext{
55 IASC, Handbook for RCS and HCS on Emergency Preparedness and Response 35 (2010)

${ }^{56}$ See IASC (2006) supra note 77, 11-13

${ }^{57}$ IASC provides for a six-step standard operating procedure for designating cluster leads: (1) consultations with local government, U.N. agencies, NGOs, and other IOs to determine capacities, leaders, cross-cutting issues, and needed OCHA support; (2) proposal is drafted by the humanitarian coordinator and forwarded to New York; (3) the head of OCHA reviews the proposal with the members of IASC; (4) the OCHA head ensures that IASC agrees at the global level; (5) OCHA informs the in-country coordinator of its decision; (6) the coordinator informs local government and country-level partners. IASC, Operational Guidance on Designating Sector/Cluster Leads in Major New Emergencies, 2 (May 2007)

$58 \mathrm{Ibid}, 8$

59 Ibid, 10

60 Ibid, 10

${ }^{61} \mathrm{Ibid}, 11-12$

${ }^{62} \mathrm{Ibid}, 13$

${ }_{63} \mathrm{Ibid}, 14-16$

${ }^{64} \mathrm{Ibid}, 18$
} 
cluster 'lead agencies'; this Humanitarian Coordinator is in turn supervised by the head of the OCHA in New York, who may hire and fire the in-country coordinator ${ }^{65}$. While such a system may be effective in certain areas such as service-delivery, additional thought can be given to maintaining experimentation and oversight of operations. ${ }^{66}$

Given that an ongoing challenge of the cluster system has been accountability to the Humanitarian Coordinator ${ }^{67}$, increasingly the oversight structure is moving toward a system of 'peer review.' This peer review system has been adopted to differing extents - ranging from informal 'lessons learned' and review of funding proposals, to more structured standards for assessment and submission of recommendations to the next higher level in the structure $^{68}$. Scholars have suggested that 'peer review' provides the seeds for an alternative model of accountability in the cluster system, one which is based on the concept of 'experimentalist' governance ${ }^{69}$.

By experimentalism, scholars refer to a range of regulatory techniques that seek alternatives both to command-and-control regulation and to the 'minimalism' of deregulatory approaches ${ }^{70}$. Experimentalism is often considered as part of an array of 'new governance' techniques ${ }^{71}$. These strategies grant broad discretion to local-level actors to pursue certain goals, with very little steering from the top down ${ }^{72}$. Some form of "peer review' is necessary to get this process going. The price of broad delegation and discretion to innovate is on-going reporting and monitoring ${ }^{73}$.

As a result, in certain areas, such as humanitarian efforts in the Democratic Republic of Congo and Myanmar, where direct accountability is often difficult given limited access to local contacts, a peer review approach has been recommended ${ }^{74}$. In turn, scholars have outlined some of the factors that have contributed to effective monitoring and inclusion. They include: (1) active and clear rulemaking and (3) reflexivity of policy making ${ }^{75}$. There is necessarily a need to find a better balance to overcome the tension between coordination and autonomy - and experimentalism, some suggest, may provide us with some guidance ${ }^{76}$. Some scholars suggest that the system of peer review and expiramentalism does not represent a transfer of power from states to international and non-governmental organizations, but a technical improvement that incorporates, rather than solves, the tension between coordination and autonomy ${ }^{77}$.

\footnotetext{
65 Ibid, 20

66 Ibid, 21

67 Steets, Julie, et al. Cluster Approach Evaluation 2: Synthesis Report 24 (2010)

68 See Heath (2012) supra note 83, 24

${ }^{69} \mathrm{Ibid}, 24$

${ }^{70}$ For the origins of the concept, see Dorf, Michael C. \& Sabel, Charles F. "A Constitution of Democratic Experimentalism", 98 Colum. L. Rev. 267 (1998)

71 See Heath (2012) supra note 83, 25. See also Sabel, Charles F. \& Simon, William H. "Minimalism and Experimentalism in the Administrative State", 100 Geo. L. J. 53 (2011); de Búrca, Gráinne, "New Governance and Experimentalism: An Introduction", 2010 Wis. L. Rev. 227. (2010)

72 See Dorf, Michael C. \& Sabel, Charles F. (1998) supra note 99, 322

73 Ibid, 288

${ }^{74}$ See Heath (2012) supra note 83, 26

75 Ibid, 27-30

76 Ibid

77 Ibid, 37
} 
Among the normative values identified with new governance ${ }^{78}$ are ownership, responsibility and follow-through by stakeholders given that solutions are derived from community input ${ }^{79}$. Deliberation on the part of diverse participants, some argue, yields wiser results ${ }^{80}$; and collaboration in many cases, may give rise to higher levels of transparency and accountability ${ }^{81}$.

On the other hand, potential shortcomings of new governance include limited accountability and legitimacy absent state oversight ${ }^{82}$ and potential inequitable access to decision making forums resulting from structural resource imbalances. Some have suggested that the voices of stakeholders with limited access to resources are unlikely to be heard resulting in a potentially elitist rather than democratic process ${ }^{83}$. Some have suggested that in order to benefit from the devolution and decentralization ${ }^{84}$, the necessary conditions for its success should include (1) the broadest possible degree of stakeholder participation compatible with effective decision making, and (2) effective and informed monitoring 85 .

New governance approaches aim to bring together insights from various interdisciplinary research in the light of rapidly changing demands in a new global economy ${ }^{86}$. Additional research must be conducted in order to achieve a sophisticated analysis of the comparative advantages of private and public action in solving social problems ${ }^{87}$. Challenging traditional regulatory regimes with top-down legal rules at one end of the spectrum, with market-based approaches at the other end, new governance aims to strike a balance between the two ${ }^{88}$. In this process, multiple governance possibilities can be continually explored; including standard setting, implementation, enforcement and forms of governmental interaction with regulated parties to bring about more effective and legitimate governance ${ }^{89}$.

\section{Summary Assessment of New Governance Findings in Light of Humanitarian Research}

The new governance literature described above provide useful insights into the contribution of new governance to expanded participation and partnership on the part of

\footnotetext{
78 E.g. see Sabel, C., \& Zeitlin, J. (2011) supra note 23

${ }^{79}$ See Van der Heijden, Jerome. (2013) supra note 18, 9

${ }^{80}$ Noveck, B. (2011). "The Single Point of Failure" in S. Van der Hof \& M. Groothuis (Eds.), Innovating

Government 77-99 (The Hague: Asserr Press, 2011), 85

81 See van der Heijden, Jerome. (2013) supra note 18, 10

82 Solomon, J. "Law and Governance in the 21st Century Regulatory State". Texas Law Review 86 (2008), 819-856.

83 E.g. De Burca, G. "New Governance and Experimentalism: An Introduction". Wisconsin

Law Review, 227(2010). 227-238; and NeJaime, D. (2009). "When New Governance Fails". Ohio State Law Journal, 70(2), 323-399.

${ }^{84}$ Alexander, Lisa T. "Reflections on Success and Failure in New Governance and the Role of the Lawyer". Wisconsin Law Review Symposium Afterword 737 (2010), 738

85 Ibid, 740-741; see also: Ali, S. "Measuring Success in Devolved Collaboration." Journal of Land Use and

Environmental Law, Vol. 26, Fall 2010.

86 Ibid, 21

${ }^{87}$ Ibid

88 Ibid

89 Ibid
} 
governments and non-state actors in solving public problems ${ }^{90}$; a learning-focused orientation $^{91}$; the use of public private partnership in regulatory reform ${ }^{92}$; the role of the state as a convener, catalyst and coordinator ${ }^{93}$; and the relationship between new governance and development of problem-solving capabilities ${ }^{94}$. This form of decision-making has largely responded to a growing dissatisfaction with the inefficiencies of rigid 'top-down' decision-making styles. In addition, recent scholarship has examined the challenges facing new governance; including ensuring participants have the necessary skills for participation $^{95}$, the development of managerial and procedural safeguards ${ }^{96}$, the difficulties of achieving stakeholder participation under conditions of social conflict ${ }^{97}$ and distributional inequalities ${ }^{98}$. These insights provide a helpful lens for examining the unique challenges of local-global coordination of developing technology innovation to respond to humanitarian crises as will be discussed below.

\section{Part III. Disaster Relief 2.0 and Examples of Public-Private Partnerships}

Reflecting insights from new governance scholarship on expanded participation in coordinated state response, within the last ten years, several public-private partnerships have emerged in collaboration with UN agencies to provide mutual assistance in humanitarian response. Several of these partnerships have focused on the development of mobile and internet technology for use in the post-disaster context. One such initiative involved a collaboration between the UNOP, the Vodafone Foundation and the Harvard Humanitarian Initiative following the 2010 Haiti earthquake. In reviewing the results of this collaboration, it was noted that "the rise of mobile phones, social networks, and open source crisis mapping tools is creating a new culture of community driven disaster preparedness and response. These tools can harness the power of mass collaboration to quickly aggregate and distribute information about urgent needs, used cloud-, crowd-, and SMS-based technologies to gather, translate, geolocate, and publish information about urgent humanitarian needs". ${ }^{99}$ Through this means, some have suggested that individuals and technical communities were better able to reach the aid community. ${ }^{100}$

In addition to the UN-Vodafone-Harvard collaboration, many other examples of partnerships to develop ICTs between the UN and businesses from the private sector include

\footnotetext{
${ }^{90}$ Lobel (a); Solomon, Jason M., 'Law and Governance in the 21st Century Regulatory State', Texas Law Review, 86 (2008), p. 819-856

${ }^{91}$ Solomon, loc. cit.; Cohen, Amy J., 'Negotiation, Meet New Governance: Interests, Skills, and Selves.' 33 Law \& Soc. Inquiry, 33(2008), p. 503.

${ }^{92}$ Alexander, Lisa T., 'Stakeholder Participation In New Governance: Lessons From Chicago's Public Housing Reform Experiment.', Geo. J. Poverty Law \& Pol'y, 16 (2009), p. 117

${ }^{93}$ Dorf, Michael C. \& Sabel, Charles E.. 'A Constitution of Democratic Experimentalism.' Colum. L. Rev., 98 (1998), p. 267; Solomon, loc. cit.; Cohen, loc. cit.

${ }^{94}$ Cohen, loc. cit.

${ }^{95}$ Ibid.

${ }^{96}$ Salamon, Lester M., 'The New Governance and the Tools of Public Action: An Introduction.' Fordham Urb. L.J., 28 (2001), p. 1611

${ }^{97}$ Alexander, loc. cit.

${ }^{98}$ Ibid.

${ }^{99}$ UN Foundation. Disaster Relief 2.0. (2011). Available at http://www.unfoundation.org/assets/pdf/disaster-relief-20report.pdf

${ }^{100}$ For summaries, see http://www.unfoundation.org/assets/pdf/disaster-relief-2-findings-1.pdf, http://www.trust.org/alertnet/blogs/technotalk/disaster-relief-20-how-technology-puts-people-at-the-heart-of-humanitarianaid/ or http://www.smartglobalhealth.org/blog/entry/technology-and-the-future-of-humanitarian-aid/
} 
partnerships with Microsoft, Hewlett-Packard, Cisco, Nokia and Ericsson in developing mobile networks and ICT in various parts of the world. ${ }^{101}$

In the Asian region, the Asian Disaster Reduction and Response Network has coordinated efforts to engage with communications technology in order to attempt to "reshape both humanitarian response and communications in disaster response". ${ }^{102}$

In addition, a large number of organizations and businesses in the private sector contribute to the development of technology for humanitarian relief efforts. Some of their achievements include the following:103 Airtel, a private mobile operator in Bangladesh, has teamed up with the Campaign for Sustainable Rural Livelihoods, the Centre for Global Change and two international NGOs (Oxfam and CARE) to provide early weather warnings to fishermen at sea using GPS. The Map Kibera project, which uses hand-held GPS devices to collect geographic information in Nairobi's largest slum, is providing important information on the availability and location of health, security, education, and water and sanitation services.

Many of these projects are independent efforts, however these often-local initiatives may sometimes be the most effective in achieving their purposes due to greater access and local knowledge. Médecins Sans Frontières ("MSF"), ${ }^{104}$ provides emergency aid to victims of epidemic and natural disasters through the Access Campaign. ${ }^{105} \mathrm{MSF}$ is also responsible for the creation of Epicentre, an on-line World Health Organization collaborating centre for research in epidemiology and response to emerging diseases. ${ }^{106}$

\section{ICT4Peace}

The ICT4Peace Foundation, a UN partner, was established in $2006^{107}$ to promote the practical realization in all stages of crisis management". ${ }^{108}$ Information and communications technology ("ICT"), ranging from the web and the Internet through personal computers to the mobile web through smartphones and Short Message Service (SMS) is increasingly seen as an important vehicle for humanitarian relief. ICT4Peace focuses on the following

\footnotetext{
${ }^{101}$ See UN partnership stories in Information and communications technologies, available at http://www.business.un.org/en/browse/partnership_stories/17?all_locales and http://ochanet.unocha.org/p/Documents/OOM_PublicPrivPartnerships_English.pdf

${ }_{102}$ Oliver Lacey-Hall, Head, Regional Office for the Asia \& Pacific, OCHA. Communication as aid. (2012). Available at http://ochanet.unocha.org/p/Documents/OLH\%20ADRRN\%20Speech\%20-\%20Phnom\%20Penh\%20090212.pdf

${ }^{103}$ See IRIN. Technology: IRIN's pick of the year 2011. Available at

http://www.irinnews.org/Report/94565/TECHNOLOGY-IRIN-s-pick-of-the-year-2011, and Technology: IRIN's pick of the year 2010. Available at

http://www.irinnews.org/Report/91414/TECHNOLOGY-IRIN-s-pick-of-the-year-2010

${ }^{104}$ MSF. About MSF. Available at http://www.msf.org/msf/about-msf/about-msf_home.cfm

${ }^{105} \mathrm{Ibid}$

${ }^{106}$ MSF. MSF Affiliated Organizations. (2011). Available at http://www.msf.org/msf/articles/2011/12/msf-affiliatedorganisations.cfm

${ }^{107}$ Paragraph 36 of the World Summit of the Information Society ("WSIS") Tunis Commitment 2005 states, "36. We value the potential of ICTs to promote peace and to prevent conflict which, inter alia, negatively affects achieving development goals. ICT can be used for identifying conflict situations through early-warning systems preventing conflicts, promoting their peaceful resolution, supporting humanitarian action, including protection of civilians in armed conflicts, facilitating peacekeeping missions, and assisting post conflict peace-building and reconstruction."

${ }^{108}$ Daniel Stauffacher. Strengthening Crisis Information Management. (2011). Available at http://www.un.org/wcm/content/site/chronicle/home/archive/issues2011/thedigitaldividend/strengtheningcrisisinformation management
} 
issues: ${ }^{109}$ raising awareness about the contribution and potential of ICT in crisis management; fostering the exchange of best practices in the field of ICT for crisis management; contributing to the establishment of broad principles derived from operational best practices, helping to integrate them into UN and multi-stake-holder processes and making ICT part of UN and global multi-stake-holder evaluation exercises.

Since 2007, ICT4Peace has provided "strategic input into how the UN system could interface with the burgeoning crisis mapping community to integrate, with appropriate and timely validation routines, crowd-sourced information into its decision and policymaking processes." 110

SecondMuse

SecondMuse is an organization that facilitates collaborative innovation and assists individuals and organizations to access inspiration through one another, using breakthrough collaboration processes, supported by technology and social media to advance understanding and communication. ${ }^{111}$ Currently, its main collaborative projects include: Random Hacks of Kindness ("RHOK"), LAUNCH, Understanding Risk, GEM and Power as Capacity.

As the Operational Lead Partner for Random Hacks of Kindness ("RHoK"), a joint initiative among Google, Yahoo!, Microsoft, NASA, HP and the World Bank, SecondMuse coordinates global volunteer efforts to develop software solutions that respond to challenges in the field of natural disaster risk and response. ${ }^{112} \mathrm{~A}$ hackathon is a "unique forum for collaborative problem solving that results in concrete software solutions that can be implemented around the world to address critical challenges". ${ }^{113}$ These challenges include helping recipients of the Supplemental Nutritional Assistance Program ("SNAP") in Philadephia $^{114}$, shelter management and post-earthquake response ${ }^{115}$.

In June 2010, SecondMuse organized six international events bringing together over 500 technologists from around the world to work together on software solutions, collaborating across time-zones, international boundaries, oceans and language barriers to create innovative, technology for vulnerable populations. ${ }^{116}$ The process was facilitated by videoconferencing among event sites, live streaming to promote collaborative development of online tools including wiki pages and IRC chat channels. Many of the applications developed through RHoK have already received support from governments, NGOs and international organizations and implemented to contribute to critical disaster risk assessment and response needs. ${ }^{117}$

In addition, SecondMuse has been collaborating closely with the Academy for Educational Development on the implementation of innovative programs using

\footnotetext{
${ }^{109}$ ICT4Peace. The ICT4Peace Story. (2010). Available at http://ict4peace.org/whoweare

${ }^{110}$ Daniel Stauffacher (2010)

${ }^{111}$ SecondMuse. What are we up to. (2012). Available at http://www.secondmuse.com/

${ }^{112}$ Random Hacks of Kindness. About. (2012). Available at http://www.rhok.org/about

${ }^{113}$ Ibid, p 10

${ }^{114}$ Ibid, p 15

${ }^{115}$ Ibid, p 23

${ }^{116}$ SecondMuse. Google, Microsoft, Yahoo!, NASA, The World Bank. (2010). Available at http://www.secondmuse.com/portfolio/view/RHoK1/

${ }^{117}$ Ibid
} 
mobile phones, SMS and cloud technologies to gather and analyze important health information from rural populations. ${ }^{118}$

Second Muse also collaborated on a project called Understanding Risk with the World to engage thousands of technical experts and practitioners from over 130 countries around the world in sharing their experiences in preparing for and responding to natural disasters. The collaborative online global community served as a forum to enable practitioners from diverse backgrounds and across disciplines to share ideas and to spur the development and use of new innovations and technologies in the field of disaster risk. The on-line collaboration lead up to the Understanding Risk Forum held at the World Bank, Washington DC in June 2010 where 400 world experts shared their work. ${ }^{119}$

SecondMuse is also helping to architect and build an open source, global seismic risk modeling platform for Global Earthquake Model, better known as GEM, a global collaborative effort bringing together national and international organizations and scientists to create open standards for calculating and communicating earthquake risk worldwide. The work started in 2009 and at the end of 2013 the first fully featured version of the model will be launched. SecondMuse was contracted for IT systems architecture, engineering leadership and management of the engineering team responsible for development of the GEM platform. ${ }^{120}$

Among the achievements of RHoK are its significant growth in recent years. RHoK organised its first hackathon in December 2009 in Silicon Valley, CA. ${ }^{121}$ By December 2012, RHoK's hackathon were held in 30 cities. ${ }^{122}$ This has enabled many around the world to participate and innovate through RHoK's coordination. For example, in Bogota, a shelter management system developed at RHoK was adopted by the national government and partners. In Santiago, TweetTheTweet Twitter syntax developed at RHoK was used to track the aftermath of the 2010 earthquake. ${ }^{123}$ Growth of the RHoK Community can be seen from the increase in the number of RHoK events, from one in November 2009 to 30 in December 2012. The number of problem definitions has also increased from 11 in November 2009 to 176 in December 2012; and the number of solutions, from 7 in November 2009 to 128 in December 2012.

RHOK events have enabled individuals from around the world to come together to develop creative solutions ("hacks") while using minimal resources in response to problems. ${ }^{124}$ After each hackathon, RHoK identifies and supports projects with high potential for deployment and impact. Beginning in June 2012, RHoK partnered with Geeks Without Bounds and their Humanitarian Accelerator, "a new six-month program focusing on business development, technical execution and deployment of high potential humanitarian technology projects." ${ }^{125}$ This is a major achievement in humanitarian action

\footnotetext{
${ }^{118}$ SecondMuse. Technology's Potential in Social and Economic Development. (2010). Available at http://www.secondmuse.com/en/portfolio/view/sms/

${ }^{119}$ For more, visit www.understandrisk.org

${ }^{120}$ For more, visit www.globalquakemodel.org

${ }^{121}$ Random Hacks of Kindness 2013 Report. Available at http://open.nasa.gov/blog/2013/03/11/random-hacks-of-kindnessreport-2013/,p 6

${ }^{122}$ Ibid, p 10

${ }^{123}$ Ibid, p 23

${ }^{124}$ Ibid, p 10

${ }^{125}$ Ibid, p 14
} 
since organizations dealing with such challenges often lack the technical expertise to drive a software project forward. Technical expertise may be provided by RHoK through RHoK's Sustainability Projects, ${ }^{126}$ including First Responder ${ }^{127}$ and Sheltr ${ }^{128}$.

RHoK "has gone from a small, focused hackathon to a vast and distributed global movement." $" 129$ From the experiences of SecondMuse, lessons may be learnt as to the importance of collaboration in addressing global challenges. ${ }^{130}$

\section{Part IV: The Path Forward and Policy Suggestions}

It is clear that there is a shifting emphasis toward greater collaboration with the private sector in developing technology for humanitarian efforts. This trend reflects insights from new governance literature on the expanded participation and partnership on the part of governments and non-state actors in solving public problems; a learning-focused orientation; and the role of the state as a convener, catalyst and coordinator. For instance, according to UNCTAD, in the realm of disaster response and development "much of the required investment will come from the private sector. Experience shows that the private sector has been the most innovative player and the major driving force behind e-business and ICT development." 131 Therefore, an "e-strategy" that merges public action with private sector initiative in a mutually supportive manner will be most effective. ${ }^{132}$ This paper will conclude by commenting on suggestions for improving public-private collaboration in post-disaster open source technology development through (a) data management in public-private partnerships, and (b) the engagement of stakeholders in the development and usage of technology for humanitarian efforts, and (c) suggestions on enhancing the cooperation of international and public bodies (UN or governments) with the private sector.

\section{Data collection and data management}

With respect to data management, following after the Haiti earthquake in 2010, several studies began to examine concrete suggestions regarding how disaster preparedness and crisis information management can be strengthened. ${ }^{133}$ Some of these suggestions include: (1) "the accelerated development and population of easily accessible datasets with essential information shared across UN and other aid agencies, to help identify, prepare for and mitigate disasters; (2) significantly improving interoperability across all systems between UN agencies and other key platforms; (3) help communities develop their own capacities and capabilities for disaster early warning, prevention and resilience; and (4) greater cooperation between governments and NGOs, based on standard operating procedures governing information sharing to help aid work. ${ }^{134}$

In addition, with respect to data collection, research has suggested that the use [of] simple, universal indicators and clear case definitions in easy-to-use formats; accuracy and

\footnotetext{
${ }^{126}$ Ibid, p 14

${ }^{127}$ Ibid, p 25

${ }^{128}$ Ibid, p 26

${ }^{129}$ Ibid, p 42

${ }^{130}$ Ibid, p 44

${ }^{131}$ UNCTAD. Partnership for Development: Information and Knowledge for Development. (2004), pp6-7. Available at unctad.org/en/docs/td394_en.pdf

${ }^{132}$ Ibid

${ }^{133}$ Daniel Stauffacher (2011)

${ }^{134}$ Daniel Stauffacher (2011)
} 
consistency; focus on data that has clear and defined utility, and use readily deployable and easily understood technology (i.e. cell phones with short messaging service (SMS) capacity) to facilitate data collection. ${ }^{135}$

With respect to data management some studies have recommended that organizations should streamline their data collection and dissemination systems and adopt a peer review system. ${ }^{136}$ In terms of human resource management, recommendations include simplifying indicators and processes, and using technologies familiar to personnel (e.g. cell phones). ${ }^{137}$ The application of innovative technologies that are easy to use, durable, and easily interfaced, yet secure and transmittable in real-time has also been suggested as a means of increasing the quality of the data management process. ${ }^{138}$ Suggestions also include using short messaging service (SMS) and damage-resistant laptops powered by solar/gear power ${ }^{139}$ since mobile phone infrastructure is generally inoperable in the days and in some cases weeks following a natural disaster.

\section{Partnerships Between International Bodies and Local Governments}

Apart from technological and managerial improvements through data collection and processing, partnership with governments at the local level is another important mechanism for improving humanitarian financing and coordination relating to technological development and usage. The cluster approach developed by the OCHA encourages the UN to reflect on key challenges, especially in light of civil society involvement, including how to best build partnership with disaster prone countries in disaster management that encompasses capacity building for preparedness and response; and how to ensure principled humanitarian action and accountability with the proliferation of humanitarian actors, including the military, the private sector, and faith-based organizations. ${ }^{140}$ While "progress has been made so far in the implementation of the cluster approach," ${ }^{141}$ greater attention can be focused on developing local capabilities to engage in joint assessment and planning in the context of disaster recovery.

\section{Development of Private-Public Partnerships}

Asset-based partnerships between the humanitarian community and the private sector are increasingly important in relief efforts. ${ }^{142}$ John Holmes, the Undersecretary-General for Humanitarian Affairs of OCHA underscored that humanitarian needs are continually rising and that current international response capacities are being stretched thin. He emphasized that "engaging other actors such as the private sector is even more important at this time, including not only cash and resource based assistance, but expertise-based partnerships that mobilize the skills and talents of the private sector in support of humanitarian assistance". ${ }^{143}$

\footnotetext{
${ }^{135}$ Harvard University. Humanitarian Health Conference 2007 - Final Report. P18 Available at http://hhi.harvard.edu/images/resources/files/hhc_2007_final_report.pdf

${ }^{136}$ Ibid, pp $18-19$

${ }^{137}$ Ibid, p19

${ }^{138}$ Ibid, pp $19-20$

${ }^{139}$ Ibid

${ }^{140}$ OCHA (2008), pp16-17

${ }^{141}$ Ibid

${ }^{142}$ World Economic Forum. Public-Private Partnerships for Humanitarian Action: Building upon Progress and Defining a Path Forward. (2008). P1

${ }^{143}$ Ibid
} 
In addition, investment in national and local capacity for response, prevention and recovery; engagement of the private sector; humanitarian recovery as part of broader social and economic development aims; and regional and international readiness to address crossborder humanitarian issues are all key areas for further development. ${ }^{144}$ 